Geographies of Displacement in a Colonial Context: Allen F. Gardiner's Writings on Australia

\title{
Elizabeth Rechniewski
}

\section{(2) OpenEdition \\ 1 Journals}

Electronic version

URL: https://journals.openedition.org/ces/4839

DOI: $10.4000 /$ ces.4839

ISSN: 2534-6695

Publisher

SEPC (Société d'études des pays du Commonwealth)

\section{Printed version}

Date of publication: 1 April 2016

Number of pages: 9-18

ISSN: 2270-0633

\section{Electronic reference}

Elizabeth Rechniewski, "Geographies of Displacement in a Colonial Context: Allen F. Gardiner's Writings on Australia", Commonwealth Essays and Studies [Online], 38.2 | 2016, Online since 05 April 2021, connection on 01 July 2021. URL: http://journals.openedition.org/ces/4839 ; DOI: https:// doi.org/10.4000/ces.4839

\section{(c) $(1) \odot$}

Commonwealth Essays and Studies is licensed under a Licence Creative Commons Attribution - Pas d'Utilisation Commerciale - Pas de Modification 4.0 International. 


\title{
Geographies of Displacement in a Colonial Context: Allen F. Gardiner's Writings on Australia
}

\begin{abstract}
Naval officer, cartographer, town planner, explorer, missionary, Allen Gardiner's life encompassed many of the roles afforded within the framework of the British Empire. This article explores his engagement with Australia through a discussion of two texts: a series of letters that he wrote to his father in 1821-1822, and a pamphlet of 1833 advocating the further exploration and settlement of the continent. It explores the overlap between the two texts and their underlying ideological coherence within the context of colonial appropriation.
\end{abstract}

The Europeans "produced and reproduced" the landscape in so far as it was defined as having a particular relationship to Europeans: the relationship took place at two levels: one as an idealised and symbolic "gaze" which constructed the land as landscape, and two, in the material construction of land as a foundation for the social relations of production. (Mahar 66)

In 1821, a young naval officer, Allen F. Gardiner (1794-1851), arrived in Sydney aboard HMS Dauntless. Already a seasoned sailor, for he had joined the navy at the age of fourteen, he had sailed many of the oceans of the world and been involved in battles with the French and the Americans, including the famous hunt and capture of the American Frigate Essex in 1813-1814. ${ }^{1}$ Enjoying on this occasion nearly six weeks of shore leave, he set out to explore the country around Sydney, venturing as far as the Blue Mountains that had been crossed by explorers only in 1813. During his travels he wrote lengthy letters to his father that recounted his experiences and recorded his opinions of the land, the settlers and convicts and the Aborigines. These letters, although never published, are held in a bound manuscript edition, the pages numbered consecutively, at the State Library of New South Wales (Letters from the South Seas). Twelve years later Gardiner wrote a pamphlet, Outline of a Plan for Exploring the Interior of Australia, published in London in 1833, that drew on his experiences during his time in New South Wales to advocate the further exploration and settlement of the continent. This article examines the ways in which Australia is represented in these two distinct genres of writing, addressed to two very different audiences: the one a kind of travel diary addressed to his father; the other a call for government-sponsored exploration and settlement that claims to be based on the scientific presentation of facts and rational argument. It explores the overlap between the two texts and their underlying coherence within the context of colonial appropriation.

Information is readily available about the life of Allen Gardiner although mainly from a particular perspective, that of his zeal in promoting the Anglican religion during the second half of his life. After a career in the Navy that saw him promoted to Commander in 1826, Gardiner, perhaps affected by the death of his wife in May 1834, perhaps frustrated at the lack of further career advancement, decided to leave the Navy

1. Gardiner distinguished himself in the capture of USS Essex and was promoted to Second Lieutenant. He subsequently served with the Mediterranean Fleet, then in the Leander and the Dauntless in many parts of the world, arriving in Sydney after a voyage to Ceylon that included Sumatra, Malaysia, the Philippines and China. Gardiner's journal of his time aboard HMS Phoebe, 1813-1814, has recently been edited by John S. Rieske, with an Introduction by Andrew Lambert (Rieske 2013). 
to pursue missionary work, a calling whose roots may be found in his early religious education. Over a period of nearly twenty years of evangelical endeavour he travelled to South East Africa, a journey recounted in Narrative of a Journey to the Zoolu Country, in South Africa (1836), then on to the remotest parts of South America and finally to the desolate shores of Tierra del Fuego, where he and his party succumbed to a lingering death by starvation in 1851 (according to the diary he left behind, in a state of religious ecstasy). Because of the seemingly superhuman resourcefulness, courage and stamina he displayed in his determination to enlighten heathen lands, his fate became an exemplar of sacrifice in the name of religion, depicted (or rather, imagined) in lithograph and frequently retold in hagiographies (Marsh) and popular religious texts. The Anglican Church commemorates his death every year on 6 September, with the "Allen Gardiner Day" as part of the Anglican Calendar for remembering martyrs of the Christian Faith. As a missionary for the Protestant religion, he combatted not only - in his terms - the Idolatry and Animism of the natives but also the "ignorant superstitions" spread by the representatives of the Catholic Church. ${ }^{2}$

The role of missionary was only the last of many that Gardiner filled in the course of his remarkable and varied life, roles that were created and sustained within the framework of the British Empire. As naval officer, he enforced the rule of the Empire through the dominance of the British Navy over the oceans of the world. Trained at naval college in the observation and depiction of natural features, he extended his observations to record the terrain, the fauna, flora and ethnographic diversity that he witnessed during his travels across the globe. As cartographer, he drew up the first maps of Southeast Africa; as town planner, he proposed the layout of the new city of Durban, where references to him remain, to this day, in the names of streets and businesses. Through his determination to bring the Bible to the natives of Natal, he played a morally ambiguous role as colonial negotiator with the Zulu King Dingane for the establishment of peace and the cession of land to the British settlers. He entered into a Faustian pact with the King whereby, in return for settler occupation of Port Natal and its surrounds, he would hand over to Dingane any fugitives from the King's domains for punishment, an agreement that would lead to a certain and horrible death for the victims (Elphick 90). He had hoped to persuade the British government to create a new colony in "Zululand" but the government declined (Lock 48). Finally he was a man of a particular class who followed the pursuits of an English gentleman across the globe (on one memorable occasion hunting the wallaby instead of the fox) and who displayed the Romantic aesthetic sensibility and appreciation of the picturesque and the sublime that signalled intellectual, cultural and affective refinement. He was also, as we shall see, an Englishman of his time in his attitudes towards race and gender, his unquestioning acceptance of British imperial superiority and his hostility to the "superstitious dogma" of the Papacy.

These roles were possible only within the context of a dominant and self-confident British Empire. The boundaries between the roles were not clear, on the contrary, they were characterised by slippage, interference and occasional contradiction, but their ultimate underlying coherence lay in the overarching ideological and geographical fra-

2. At the end of a visit to Peru in 1822 Gardiner expresses the hope that the Indians will soon "meet the protection they deserve under a mild and equitable Government and exchange the Rosary and Crucifix grafted by superstition upon their ignorance for the less ostentatious realities of a purer Creed." ("Letters" 137-8) 
mework of Empire. This vast enterprise of global domination supposed not only the exercise of physical force but also an accompanying mindset that read the environment as an object of appropriation.

\section{Letters from the South Seas (1821-1822)}

Gardiner arrived in Sydney on 24 June 1821 aboard HMS Dauntless, an event recorded on 30 June in the "Ship News" of The Sydney Gazette and New South Wales Advertiser, although the paper's report that the ship had called "merely to refresh" and would depart again "with as little delay as possible" for South America was to be disproven, for Gardiner enjoyed nearly six weeks of shore leave. He used the time ashore to undertake extensive trips around Sydney and into the Blue Mountains, recounting his experiences in regular and lengthy letters to his father Samuel Gardiner (1755-1827), a man of substance who had been appointed High Sheriff of Oxfordshire in 1794. Gardiner spent the first week in and around Sydney, venturing as far as Parramatta, where he visited the Native School, the Female Factory and the estate of Sir John Jamison at Regentville; he journeyed as far as the junction of the Warragamba and Parramatta rivers before returning to Sydney on 28 June. This tour is described in a letter dated 2 July 1821, written from Sydney, Port Jackson. On 3 July he sets off on a more ambitious journey inland, venturing as far as Bathurst in the Blue Mountains, from where he wrote a letter to his father on 7 July. The 20 July finds him back in Sydney, while the final letter that concerns this stay in Sydney is written on 1 August, shortly before the ship's departure on 3 August.

Gardiner's letters are not merely accounts of his activities, but undertake to satisfy his father's evident curiosity as to the nature of this unfamiliar country and its people: he writes at one point that his father "will be expecting to hear something of the natives of this country" (42). He endeavours to satisfy his father's curiosity through a comprehensive and detailed account of the different aspects of the colony: the terrain, climate, landscape and people. Adopting variously an aesthetic, economic, ethnographic and naturalist perspective, he frames the landscape through Romantic tropes; speculates about the reasons for the marsupial pouch, for "nothing is superfluous in nature" (39); assesses the soil, agricultural potential and economic future of the colony; and, as his father is expecting, describes in some detail the Indigenous peoples. The letters take up the interests and observations that Gardiner has been accustomed to record in his naval journals that reveal, writes Lambert, "the scientific curiosity of a newly minted trainee naval officer with the aesthetic sensibilities of a young man trained to paint coastal perspectives" (Lambert 3). His letters provide a welcome and little-known addition to the relatively few accounts that we have of the young colony; they also provide a case study of the ways in which the "colonial gaze" represents and appropriates the lands within its reach.

\section{The Aesthetic Gaze: the Romantic, the Sublime and the Picturesque}

Sensibility to the aesthetic and understanding of the categories of the picturesque and the sublime were integral to the refinement of mind that marked an English gentleman. Gardiner's letters are replete with illustrations of his aesthetic appreciation of his surroundings, from the picturesque pool: "the reflection of this rocky parapet fringed by 
the elegant swamp bark and often cushioned with moss, had a beautiful effect in the water" (12), to "the sublimity of the scene" (21) that greets him as a new vista opens out before him. The element of surprise (and contrast) contributes to the impact of the scene, as coming to the edge of a ridge he notes that "the situation was as romantic as unexpected" (20).

These observations play a dual function: they attest to the superior sensibility of the English gentleman but also subsume the countryside under the categories developed by "civilised" man. Paul Carter argues that the Europeans' aesthetic depiction of the landscape, whether of wild scenery or picturesque and peaceful vistas "gave the impression of visual cultivation, of an aesthetic history with a civilised future" (237) and made it possible for the observer to find his place within it:

The picturesque in Australia made the space of travelling visible to the traveller. It realised for him his own historical destination - to travel or to settle down. [...] To call [the scenes] picturesque was to attribute to them the observer's own heightened sense of possession, his sensation of suddenly being at home in the world. (Carter 243)

\section{The Naturalist's Gaze}

As a man of the Enlightenment, Gardiner takes pains to observe closely and to describe in careful detail (sometimes with illustrations) the flora, fauna and natural features of the land. This scientific discourse constitutes a "field of visibility" that foregrounds a self-contained and comparative descriptive system, offering another set of categories that the white man could impose on the world, to understand, describe and order it. For Mary Louise Pratt this gaze "elaborated a rationalizing, extractive, dissociative understanding which overlaid functional, experiential relations among people, plants and animals," thus excluding the particular history and use value of plants, animals and land to the Indigenous peoples (38). The Naturalist's gaze "naturalises": "Through mastery of this discourse, the (letter'd, male, European) eye that held the system could familiarise ('naturalise') sites/sights immediately upon contact, by incorporating them into the language of the system" (31).

The Aesthetic gaze and the Naturalist gaze might seem incompatible - the one eschews scientific precision for the evocation of aesthetic appreciation tinged with emotional and even moral judgement via a rich vocabulary of excess. The other employs a precise, unemotional vocabulary of careful and neutral comparison and description. However, they can be seen in the context of colonial appropriation as complementary perspectives, asserting forms of axiological and scientific mastery over the country. Both offer, moreover, a perspective that conspires to eliminate the Indigenous peoples from the picture, for the Aborigines are absent, indeed absented from this landscape, the connection between land, people and activity is broken. When they are described, as we will see later, they are often sitting passively around their fires or dancing.

\section{A Land that is Compatible and Familiar}

As Gardiner seeks to evoke for his father at home his impressions of this unfamiliar land, his emphasis is often on the similarities he finds: on 28 June his party journeyed to the junction of the Warragamba and Parramatta rivers which he describes through a comparison with the Wye Valley, calling the "frequent windings beneath their preci- 
pitous banks a succession of wild and romantic scenery by no means inferior to many parts of the Wye" (11). Such comparisons, though perhaps inevitable in this generic context, establish a link to the homeland and help to make the unknown familiar and recognisable. ${ }^{3}$ The fauna may look strange, but they - and the land itself - nevertheless lend themselves to the pursuits of an English gentleman, since Gardiner describes a "very fine hunt," "one of the [wallabies] affording an excellent chase over some clear ground which enabled us to get in at the death" (37).

Where the colonists have established themselves in this country, their estates are flourishing: at Sir John Jamison's estate of Regentville, Gardiner comments on the rich black loam, the abundant crops of wheat and Indian corn, and the garden full of native and European fruits that have "found an asylum in this genial climate" (11). An accumulation of positive adjectives, given additional emphasis through the repeated use of intensifying adverbs, describes the potential of the land: "With regard to local advantages, few countries are more bighly favour'd, the climate is delicious and the soil, excepting within about twenty miles of the coast, remarkably fertile and altho' intersected by no Rivers of any magnitude, extremely well-watered' (55, emphasis added).

On the transformative powers of the settlers in bringing forth the fruits of this land, Gardiner writes with rhetorical flourish: "There is perhaps no instance of so distant a Colony having arrived at so flourishing a state in so short a period. It is now but 33 years since it was first settled by Governor Phillip" (56, emphasis added). Already, he points out, it has exported wool to the Mother Country. The logical conclusion of such edenic descriptions and positive comparisons with other colonies is that it must be the duty of the white man to unlock the potential of this "favored land" (20) and transform it into the Arcadia of plenty that God intended. However, as Mahar writes of similar descriptions of the unrealised potential of New Zealand: "in reality life in Arcadia was all about land, power and the control of resources" (70).

The land is thus described as both aesthetically pleasing and potentially productive. However these positive representations are not echoed in the portrait Gardiner offers of the Aborigines whose incompatibility with civilised living, whether on moral, aesthetic or intellectual grounds, is central to his depiction. He shares the prevalent view of the hierarchy of the races: in Australia "the Human Species is here perhaps in the very lowest scale of degradation," (4) "[a] more humbling portrait of human nature can not well be imagined" (51). Commenting on John Barrow's descriptions of the African natives, Mary Louise Pratt writes: "To the improving eye, the potentials of the Eurocolonial future are predicated on absences and lacks of African life in the present" (61). The Australian Aborigines are similarly described by Gardiner using a vocabulary that insistently evokes lack, negation, and transience:

[O]wing to their aversion to industry and their migratory mode of living, so unfriendly to increase, being extremely scanty, the Human Species is here perhaps in the very lowest scale of degradation, without clothes, without houses, unless we dignify the temporary shelter afforded by a strip of bent bark by that name; roaming about in small tribes of 20 or 30 in quest of kangaroo-rat and opossum on which they chiefly subsist. Even their arms, on which most Savages display some little ingenuity, are of the rudest kind. (42)

Aesthetically, their appearance is represented as repulsive:

3. During his sea voyages in the southern hemisphere Gardiner noted with amusement the places that were situated at the corresponding latitudes in the northern hemisphere. ("Letters" 59-60) 
The natives in the neighbourhood of Sydney are of the middling stature, slightly limbed but straight and active; the complexion is a sooty black, the hair curled but not woolly with the nose as flat as the African negro and the lower part of the face very prominent. The countenance of the women is equally bideous, their clotted hair standing out in all directions, occasionally intermixed by way of adornment with feathers, kangerou teeth or fish bones, which does not a little contribute to their savage appearance. (45, emphasis added)

The initial lines of the description, apparently neutral in tone, are overlaid by the unambiguously pejorative "hideous," a term that carries overtones of both aesthetic and moral condemnation. This term is used again in his description of a "Corrobora" [sic]: Gardiner cannot bring himself, he writes to his father, to describe their actions as a dance, ${ }^{4}$ while: "The accompanying song was equally novel and elegant with the rest of the performance; all throats were strained in chorus, of a more bideous yell it is not possible to conceive" (49, emphasis added). The term occurs yet again when Gardiner visits the Female Orphan Institution in Parramatta where he sees seventy-two (white) children taught according to "Bell's system" with the result that "a great deal of order and neatness was apparent throughout" (15). He is affected by the contrast between their "sweet voices" and the "hideous yell of the Savage" who, only thirty years before, was "carousing in this delightful spot" (15, emphasis added). His visit to the Native School furnishes moreover another occasion to compare unfavourably the white and Indigenous races. Of the children at the Native School he writes: "Their appearance was stupid in the extreme and much care and severity was necessary to rouse them from their natural state of filth and indolence" (7).

He laments, as a man of "sensibility", the cruel treatment that the Aborigines inflict on their own people, on the young men who undergo painful initiation ceremonies, and on the women who, he claims, are "courted" by being knocked nearly senseless before being dragged to their new home (46). The latter contention in particular, which he does not claim to have witnessed, bears the hallmarks of European myth. Such reports cast further discredit on the Aboriginal way of life and suggest that the Indigenous people have to be "saved from themselves." The colonists, he asserts, have tried to bring the benefits of civilisation to these "wretched people" through the establishment of a settlement for them at Elizabethtown. ${ }^{5}$ However, "altho' living in the very heart of a flourishing colony, familiarised to our language which many speak remarkably well, and accustomed to witness all the various acts of civilisation, few are to be seen in this new asylum" (50-51), and none have lost "a predilection for their former habits" (51).

Gardiner provides detailed descriptions of several of the tools and weapons used by the Aborigines: "an extraordinary missile called a Bummarang [sic]," the Wammera (throwing stick) and the Waddie, and the shields Tourow and Elooman (43-4). The Aborigines' great skill in using these implements is acknowledged but of course these arms have already been dismissed as being "of the rudest kind." There are occasional glimpses of Gardiner's interaction with the Aborigines: he records their laughter when he tries to throw the Wammera for example (44). However it is interesting to note that he does not record whether natives guided him on his journeys into the Blue Mountains,

4. An implicit comparison, perhaps, with the "select ball and supper" aboard the Dauntless, to which the ship's officers invited the "Ladies and Gentlemen of the Colony" on 23 July 1821 (Sydney Gazette and New South Wales Advertiser. 28 July 1821: 3 ).

5. Governor Lachlan Macquarie set aside land near Elizabeth Bay as a "model fishing village" for Aboriginal people in 1820 ("Aboriginal People and Place"). 
or whether he met Aborigines on his extensive travels. He describes the presence only of urban Aborigines who appear "out of place" in the European world that has been thrust upon them, while the country he passes through seems to be empty of them.

The combined effect of Gardiner's diverse representations of the land and its people is to "displace" the Aborigines, to suggest that the "Savages" are "out of place," a source of dissonance at odds with the beauty of the landscape and an obstacle to its development into the Arcadia it promises. The Europeans, on the other hand, are immediately at home here in a country that is familiar, compatible and that yields up its fruits to their productive industry. These representations thus tend towards a dual effect: they empty the landscape of its original inhabitants and install the Europeans as its rightful occupants. As Pratt writes: "The European improving eye produces subsistence habitats as 'empty' landscapes, meaningful only in terms of a capitalist future and of their potential for producing a marketable surplus" (61).

\section{Outline of a Plan for Exploring the Interior of Australia (1833)}

Gardiner returned to Sydney in HMS Dauntless on 12 March 1822, an event recorded in the Sydney Gazette which notes that the ship had had "an encounter with the natives of the Marquesas to punish them for cutting off the boats of a whaler" ("Sydney"). He writes little to his father of this second stay in Sydney other than to record the invitations he received to social events and to note that it was on this occasion that he learned of the death of the Queen and the replacement of Governor Macquarie by Sir Thomas Brisbane. A decade later, however, Gardiner returned to the subject of Australia, but this time with a different aim and audience: his Outline of a Plan for Exploring the Interior of Australia (1833) was one of several projects advocating exploration of the continent drawn up in this period by a group of British officers that included Thomas J. Maslen and James Vetch.

Maslen was the author of A Friend of Australia (1830), an extensively argued and detailed tome on the advantages to be gained from exploring and settling the rest of Australia, a task to which he brought the fruits of his voracious reading and his experience in India. It was published anonymously and some libraries until recently recorded Gardiner as its author. Vetch was the author of Considerations on the Political Geography and Geographical Nomenclature of Australia (1836), a text that combines advocacy for further exploration with a comprehensive system for dividing up and naming the parts of the continent. It is noteworthy that all three men served in the Army or Navy: Maslen had served in the East India Company Army while both Vetch and Gardiner were in the Navy. Maslen, Vetch and Gardiner were able to travel the world, observe, report, and often intervene in the colonial enterprise because of the reach of the British Army and Navy; their military profession also supplied them with the knowledge, expertise, training and experience that they brought to bear on their engagement with Australia. In drawing up plans for exploration of the continent, Maslen and Vetch had to rely, however, on second-hand reports and on their experience in other lands since they never visited Australia. Gardiner, by contrast, can and does cite on occasion his first-hand knowledge of the continent, ${ }^{6}$ lending his arguments greater credence and authority.

6. Stating that the Blue Mountains are merely an "insignificant range" and not therefore a major obstacle to exploration, Gardiner adds "the author speaks from personal observation, having traversed the country for some distance beyond Bathurst” (4). 
It is also significant that all three men were associated in some way with the Royal Geographical Society founded in London in 1830, that actively sought to recruit the collaboration of Army and Navy officers in its ambition to refine and extend geographical knowledge (Barrow, "Prospectus" ix). Although he was not a member of the Society, Gardiner must have been aware of its objectives and its interest in recruiting travellers to report on little-known regions of the world, since in 1834 he wrote to a long-standing committee member, Lord Bexley, giving details of his proposed journey to the Natal and the routes and equipment he intended to take ("Letter to Lord Bexley"). As the Chairman John Barrow had made clear in his founding address, the Society was particularly anxious to prove its worth by encouraging the exploration of uncharted regions of the world ("Prospectus" ix-x) and, in commenting on a report on the nascent Swan River colony, Barrow had identified Australia as one of the areas most deserving of attention ("Swan River Colony" 1-2). During this early period the Society was prepared to envisage the practice of "speculative geography," believing that conjectures as to the nature of the terrain to be encountered in the uncharted areas of the world would better prepare explorers for the conditions they would find there (Graves and Rechniewski 65). In proposing his plan for the exploration of Australia Gardiner undertakes just such conjecture, considering the likely terrain to be encountered and the length and arduousness of the journey, before proposing several possible routes across the continent.

Onto the "vast unknown" that is the map of Australia, Gardiner traces three possible routes for exploring as much of the country as efficiently as possible, with the primary object of finding "navigable rivers and interior lakes" (Outline 7). His proposed routes dissect the featureless map with a geometrical precision that seems to simplify the task ahead. After discussing the apparent advantages and difficulties of each route, he advocates mounting an expedition from the Swan River settlement, moving inland in a north-easterly direction, with a choice of a northerly or southerly route thereafter. His recommendation relies on a series of assumptions about the likelihood of the chosen route following higher ground and thus meeting fewer obstacles such as "bogs and morasses," while streams "being encountered nearer their sources would be more fordable" (9). He calculates in some detail (though in far less detail than Maslen) the provisions necessary for the expedition and makes suggestions as to the equipment the exploring party will need.

\section{Marshalling the Arguments for Exploration}

The project of exploration put forward in Outline is "respectfully suggested to the public" but more specifically drawn to the attention of "government, or of some scientific society" that might be able to fund exploration (3). It is therefore a very different kind of text to the correspondence sent to his father: the nature of the addressee and the objectives of the texts suppose different generic conventions that are realised in their contrasting tone, style and vocabulary. A persuasive text, Outline marshals a range of materialistic, patriotic and supposedly idealistic arguments to build its case for exploration. Like Maslen and Vetch, Gardiner presents exploration as in the interests of the British nation, that "commercial nation" to whom his Outline is dedicated, and which in the long term may find in the Australian colonies a market for British manufacture (7). Like Maslen, he sees the opportunity for the Australian colonies to employ "the ener- 
gies of all our surplus population" since "[f] or aught we know, the central parts of this country may abound with veins of rich ore, or beds of coal or useful indigenous plants" (5). Gardiner castigates the "supineness" and "apathy" of the British government that may allow foreigners to seize the riches of the continent if the British do not rapidly lay claim to the whole of it (6). Finally he asserts it is Britain's duty "to extend the range of science and civilisation," for the "blanks on the map" that "deform our modern atlases and [...] disgrace the intelligence and enterprise of the nineteenth century" are a reproach to the spirit of progress (6-7).

The representations that inform his portrait of the New South Wales colony in 1821 are present also in the 1833 text and form the underlying premises on which he argues for exploration and settlement. Thus he describes the country as a wasteland, as "a wilderness untrodden by civilised man" (6) and as these "southern wildernesses" (16). It is, however, a land of unfulfilled promise, enjoying "a climate and soil comparable to some of the finest portions [of Europe] such as Spain and Sicily," (3) while the Bathurst and Liverpool plains offer "one of the finest grazing countries in the world" (5). The country is represented as welcoming and familiar, inviting occupation by the white man, for the latter quote suggests that it is "designed" to host cattle. It is therefore, he argues, the duty of Europeans to transform this land, "to unfold the manifold treasures of Providence" that lie unexploited there (6). As David Spurr writes: "the exploitation of colonised territories thus becomes a moral imperative as well as a political and economic one" (29). We might add that in the eyes of Gardiner it is also a religious imperative, although in the two texts studied here the religious motive is not yet prominent. ${ }^{7}$

The Outline contains only two references to the Indigenous peoples: the first refers to their "wandering character," (7) the second to their possible "hostility" (12). The potential role of Aborigines as guides or informants is never recommended nor even envisaged. Ammunition and arms make up by far the heaviest component of the baggage that Gardiner considers necessary for the exploring party, for this is to have a predominantly military composition: a Commander, a second in command, a surgeon and botanist, a non-commissioned officer and eight marines (11).

Through the comparison of these two texts on Australia authored by Gardiner, the link between certain forms of representation of the land and people, whether aesthetic, scientific, ethnographic, political or economic, and the colonial project of appropriation, becomes clear. The theme of this issue, "Geographies of Dislocation," can thus be given, through recognition of the impact of Gardiner's roles as naval officer, tourist, ethnographer, imperial negotiator and town planner, a very concrete meaning: the geographical advance of the British Empire and the expansion of European settlement were accompanied and prepared by a conceptual mindset that disconnected and "displaced" the Indigenous peoples from their lands. Indeed their occupation of the land was represented as tenuous (they are merely "wandering" tribes), and unjustified because they were disengaged from the "real" labour of its productive transformation. As Spurr writes: "Colonial intervention thus responds to a threefold calling: that of nature which calls for the wise use of its resources; that of humanity, which calls for universal betterment; and that of the colonised, who call for protection from their own ignorance

7. In the "Letters," however, he foreshadows a period "at no great distance" when "these unfortunate tribes, now so rude and ignorant, may emerge from the thick darkness which surrounds them, to the confusion of those who still trifle with superior advantages" (52). His evangelical calling postdates his engagement with Australia. 
and violence" (34). All three of these kinds of arguments can be found in Gardiner's writings on Australia which offer a particularly coherent illustration of the conceptual means by which the landscape is emptied of its encumbering native peoples and laid open to appropriation, indeed expropriation, by Europeans.

Elizabeth RECHNIEWSKI

The University of Sydney (Australia)

\section{Works Cited}

BARrow, John. "Prospectus of the Royal Geographical Society." Journal of the Royal Geographical Society of London 1 (1831): vii-xii.

—. "State of the Swan River Colony, 1 January 1830." Journal of the Royal Geographical Society of London 1 (1831): 1-16.

CARTER, Paul. The Road to Botany Bay: An Exploration of Landscape and History. London: Faber \& Faber, 1987.

City OF Sydney. "Aboriginal People and Place.” 3 March 2015 <http://www.sydneybarani.com.au/ sites/aboriginal-people-and-place> . Accessed 25 November 2015.

ElPHICK, Richard, and Rodney DAVENPORT, eds. Christianity in South Africa: A Political, Social and Cultural History. Berkeley: U of California P, 1997.

Gardiner, Allen F. Letters from the South Seas. Library of New South Wales, MLMSS 8112, 1821-1822. Manuscript.

-. Outline of a Plan for Exploring the Interior of Australia. London: James Duncan, 1833.

—. "Letter to Lord Bexley, giving details of proposed journey to Natal." Falmouth, 30 August 1834. Royal Geographical Society, LMS G 3. Manuscript.

-. Narrative of a Journey to the Zoolu Country, in South Africa. By Captain Allen F. Gardiner, R.N., undertaken in 1835. London: W. Crofts, 1836.

Graves, Matthew, and Elizabeth ReChniewski. "Speculative Geographers: Imagining the Australian Continent in the 1830s." Visualizing Australia: Images, Icons, Imaginations. Ed. Renate Brosch, and Kylie Crane. Trier: Wissenschaftlicher Verlag Trier, 2014. 61-82.

LAMBERT, Andrew. "Introduction.” Rieske 1-28.

Lock, Ron. Zulu Conquered: The March of the Red Soldiers, 1822-1888. London: Frontline Books, 2010.

MaHAR, Cheleen Ann-Catherine. "Landscape, Empire and the Creation of Modern New Zealand." Landscape and Empire 1770-2000. Ed. Glenn Hooper. Aldershot: Ashgate, 2005. 65-78.

MarSH, John W. The Story of Commander Allen Francis Gardiner, R.N. with sketches of missionary work in South America. London: James Nisbet, 1883.

Maslen, Thomas J. The Friend of Australia or a Plan for Exploring the Interior and Carrying on a Survey of the Whole Continent of Australia. London: Hurst, Chance, and Co., 1830.

PRATT, Mary Louise. Imperial Eyes: Travel Writing and Transculturation. London: Routledge, 1992.

RIESKE, John. S. Hunting the Essex. A Journal of the Voyage of HMS Phoebe 1813-1814 by Midshipman Allen Gardiner. Barnsley: Seaforth Publishing, 2013.

SpurR, David. The Rhetoric of Empire: Colonial Discourse in Journalism, Travel Writing and Imperial Administration. Durham: Duke UP, 1993.

"Ship News." The Sydney Gazette and New South Wales Advertiser (Saturday 30 June 1821): 3.

"Sydney." The Sydney Gazette and New South Wales Advertiser (15 March 1822): 2.

VETCH, James. "Considerations on the Political Geography and Geographical Nomenclature of Australia." Journal of the Royal Geographical Society of London 8 (1838): 157-69. 